\title{
THE INFLUENCE OF ROUTINE AGRICULTURAL ACTIVITIES ON THE QUALITY OF WATER IN A TROPICAL RICE FIELD ECOSYSTEM
}

\author{
Al-Shami, S.A. ${ }^{*}$ - Che SAlmah, M.R. - Siti AZIZAH, M.N. - Abu Hassan, A. \\ School of Biological Sciences, University Sains Malaysia, 11800 Penang, Malaysia \\ (phone: +6046591121 , fax: +6046565125$)$ \\ *Corresponding author \\ e-mail: alshami200@yahoo.com \\ (Received $21^{\text {st }}$ June 2009 ; accepted $25^{\text {th }}$ January 2010)
}

\begin{abstract}
Physico-chemical parameters of the rice field water of Bukit Merah Agricultural Experimental Station (BMAES), Penang, Malaysia were investigated during two cultivation seasons of 2004/2005. The selected variables showed wide ranges of variation. Except for total organic matter (TOM) and total suspended solid (TSS), the values of all variables were significantly different at all sampling occasions. Most of the physico-chemical parameters showed significant relationship to the water level either in the presence of rice plant or after harvesting of the crop. The rice agroecosystem is a complex ecosystem due to the interaction of aquatic organisms, including algae and macrophytes. This unique swampy ecosystem is usually disrupted during ploughing, drainage, harvesting and application of fertilizers and pesticides. It was concluded that the agricultural activities in this rice field contributed effectively in creating the wide variations in the values of physico-chemical parameters.
\end{abstract}

Keywords: water parameters, rice field ecosystem, agricultural activities

\section{Introduction}

The rice field is a unique man-made environment with high diversity of aquatic organisms. In South East Asia rice fields cover over 70 million hectare (Lim, 1990). The rice fields have been recognized as an important source for producing cheap protein, such as fish and crab (Ali and Ahmad, 1988) and form an important component in the economic life of the rural people (Lim et al., 1984). The rice field ecosystem is a dynamic and highly disturbed ecosystem. Routine agricultural practices including ploughing, draining, fertilizer and pesticide applications, harvesting and desiccation brought about the wet and dry climate cycles influenced the diversity the aquatic community (Che Salmah et al., 1998). Generally, rice fields show a wide variation of water parameters such as temperature, $\mathrm{pH}$, dissolved oxygen, conductivity, nitrate and phosphate (Lim, 1990). This study was aimed at investigating the effect of rice cultivation practices in the rice agroecosystem on the quality of rice field water.

\section{Materials and methods}

\section{Description of the study area}

This study was conducted at the Bukit Merah Agricultural Experimental Station (BMAES), in Permatang Pauh, Seberang Perai, Penang. The station is located in Bukit Merah, about $20 \mathrm{~km}$ from Butterworth at latitude $5.417^{\circ} \mathrm{N}$ and longitude $100.417^{\circ} \mathrm{E}$. The 16.5 ha irrigated research station is administered by the Agriculture Centre of Bukit Merah, Seberang Perai under the supervision of Malaysian Agricultural Research and 
Development Institute (MARDI) of Bumbung Lima, Seberang Perai. Rice seeds (variety MR220) are produced at this station and distributed to the farmers in surrounding areas (Fig. 1).

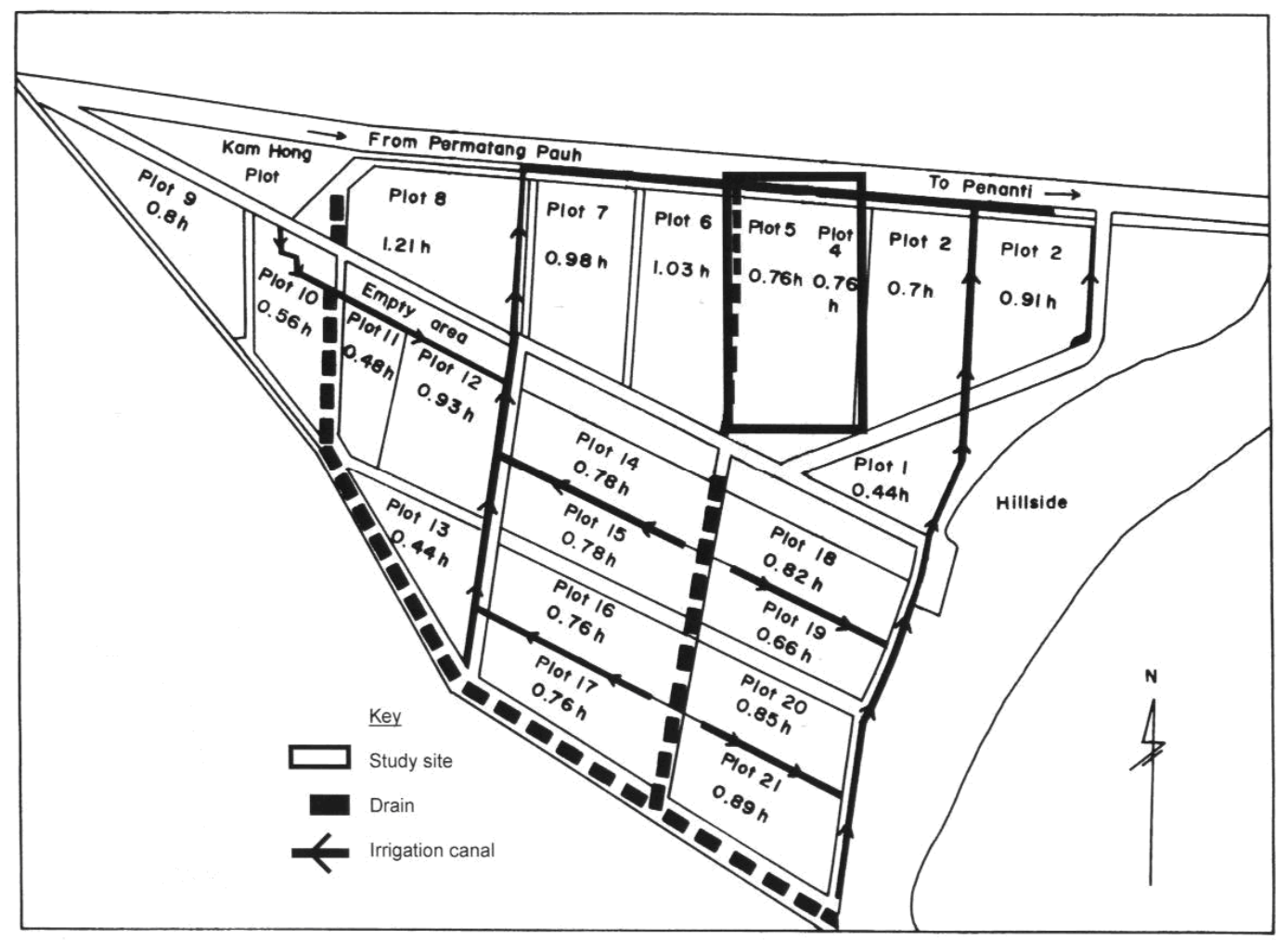

Figure 1. Layout plan of study area at Bukit Merah Agricultural Experimental Station

\section{Environmental study}

The water layer closer to the sediment (approximately $15 \mathrm{~cm}$ deep), was easily measured in situ for their $\mathrm{pH}$, electrical conductivity (EC), temperature and dissolved oxygen (DO) contents. Dissolved oxygen $\left(\mathrm{mg} \mathrm{L}^{-1}\right)$ and water temperature $\left({ }^{\circ} \mathrm{C}\right)$ were measured with a DO meter (YSI-57), whereas the $\mathrm{pH}$ of the water was recorded using a Termo Orion-Model $210 \mathrm{pH}$ meter. The water conductivity $\left(\mu \mathrm{S} \mathrm{cm}^{-1}\right)$ was measured with an SCT meter (YSI-55). Water samples were collected from the sampling area in $500 \mathrm{ml}$ plastic bottles. These bottles were sterilized with concentrated $\mathrm{HCl}$ (Ali et al., 2002) prior to sampling and rinsed three times with rice field water before taking the actual water samples. They were kept in a cool Coleman ${ }^{\circledR}$ chest during transportation to the laboratory. In the laboratory, the samples were transferred into a freezer $\left(-20^{\circ} \mathrm{C}\right)$ prior to analysis (Che Salmah et al., 1998). The measurements of each variable were replicated three times and the mean and range values were recorded.

The Total Organic Matter (TOM) of the sediment was analysed following the method of (Faithful, 2002). First, the soil was air dried at room temperature. Then it was crushed in a mortar and pestle and sieved using a $0.5 \mathrm{~mm}$ sieve. Ten gm of the sieved soil $\left(\mathrm{W}_{0}\right)$ was weighed using a digital balance (A\&D Model ER-180A, Japan) and placed in a dry and clean crucible disc. It was dried in an oven (Mermmert model 854 
Schwabach, Germany) at $100{ }^{\circ} \mathrm{C}$ overnight. The dry sample was recorded as $\mathrm{W}_{1}$. The weight of the sample after water elimination was calculated as $=\mathrm{W}_{0}-\mathrm{W}_{1}=\mathrm{W}_{2}$. The sample was placed in a furnace (Blue M Model M15A-1A) at temperatures of 450-500 ${ }^{\circ} \mathrm{C}$ for 3-4 hours. The sample was then reweighed and labelled as $\mathrm{W}_{3}$. The total organic matter (TOM) was calculated as TOM $\%=\mathrm{W}_{3} / \mathrm{W}_{2} \mathrm{X} 100$. These procedures were replicated three times and the mean values were recorded.

Total Suspended Solids was determined using the method of (Tomar, 1999). A 500 $\mu \mathrm{m}$ filter paper was dried overnight in an oven (Mermmert model 854 Schwabach, Germany) at $100{ }^{\circ} \mathrm{C}$. It was weighed using a digital balance (A\&D Model ER-180A, Japan) and labelled as $F_{1}$. The filter paper was placed in the filtration funnel (Millipore $^{\circledR}$, USA) and $100 \mathrm{ml}$ of water sample was poured into it. When all water has passed through the funnel, the filter paper with filtered material was removed from the funnel and dried overnight in an oven at a temperature of $100{ }^{\circ} \mathrm{C}$. It was reweighed and labelled as $F_{2}$. The total suspended solids were calculated as $F_{2}-F_{1}$. Three samples were analysed and the mean values were recorded.

The nitrogen-nitrate and phosphate contents in the water were determined using a YSI 9100 Photometer test kit. A water sample was filled in a test tube to $10 \mathrm{ml}$ mark and the appropriate reagents for the tests were added following the kit procedures. The mixture was left 10 minutes before taking the light absorbance readings at selected wavelength. The wavelength set for the phosphate content was $640 \mathrm{~nm}$ and the nitrate content was read at $570 \mathrm{~nm}$. Three readings were taken for each compound and the mean values were recorded.

\section{Results}

Selected physico-chemical variables of the rice field showed wide ranges of variations (Table 1). Water level varied widely depending on rice cultivation stages. Water was either drained or coincidentally low due to the absence of rain during plough, seeding, harvest up to the early part of the fallow phases. Growth patterns in the field indicated there were two rice crops; from late September 2004 to late of December 2004 and from early April 2005 to late July 2005. These rice crops were separated by growth of grasses and other weeds during fallow phase.

The $\mathrm{pH}$ however, showed smaller ranges with a mean of 6.27 rendering the field a slightly acidic environment. In general the conductivity of the water in the study area was quite high and ranged between 15 and $250 \mu \mathrm{S} \mathrm{cm}^{-1}$. Biweekly mean nitrate were relatively high in this study area and the highest concentration $\left(2.71 \mathrm{mg} \mathrm{L}^{-1}\right)$ was detected in late August 2004. The mean of soluble phosphate levels were relatively high and ranged from 0.02 to $1.83 \mathrm{mg} \mathrm{L}^{-1}$. The amount of total organic matter (TOM) in the sediment varied according to the physical and chemical conditions of the field. The mean of TOM in the study area was considered high (5.68\%). Except for total organic matter (TOM) and total suspended solid (TSS), the values of all variables were significantly different at all sampling occasions (Kruskal-Wallis at $\mathrm{P}<0.05$ ).

Table 2 shows the relationship of these variables to the fluctuation of water level. The $\mathrm{pH}$, dissolved oxygen and total organic matter (TOM) showed no relation to the water level in the field. However, other variables showed a significant correlation with the water level (Fig. 2: a-e). The water was considered as a key factor controlling other variables and the changes in other variables values were closely followed the fluctuation in water level.

APPLIED ECOLOGY AND ENVIRONMENTAL RESEARCH 8(1): 11-18. http://www.ecology.uni-corvinus.hu • ISSN 15891623 (Print) • ISSN 17850037 (Online) (C) 2010, ALÖKI Kft., Budapest, Hungary 
Table 1. Mean and ranges of water parameters, rice plant height and total organic matter in the sediment of rice field plots.

\begin{tabular}{|c|c|c|}
\hline Parameter & Mean \pm SE & Range \\
\hline Water Level (cm) & $13.99 \pm 0.486$ & $1.5-35$ \\
\hline Plant Height (cm) & $51.69 \pm 1.893$ & $0-130$ \\
\hline pH & $6.271 \pm 0.021$ & $5.15-7.7$ \\
\hline Conductivity $\left(\mu \mathrm{Scm}^{-1}\right)$ & $84.06 \pm 2.283$ & $15-250$ \\
\hline Dissolved Oxygen (mg l-1) & $2.87 \pm 0.073$ & $1.06-6.87$ \\
\hline Temperature $\left({ }^{\circ} \mathrm{C}\right.$ ) & $29.21 \pm 0.010$ & $23-34$ \\
\hline Total Organic Matter (\%) & $5.68 \pm 0.062$ & $3.03-8.77$ \\
\hline Total Suspended Solids ( $\mathrm{mg} \mathrm{l}^{-1}$ ) & $48 \pm 0.11$ & $5-110$ \\
\hline Phosphate (mg l' $\left.\mathbf{l}^{-1}\right)$ & $0.43 \pm 0.020$ & $0.02-1.83$ \\
\hline Nitrate-Nitrogen $\left(\mathrm{mg} \mathrm{l}^{-1}\right)$ & $0.57 \pm 0.030$ & $0.044-2.713$ \\
\hline
\end{tabular}

Table 2. Correlation coefficient of physico-chemical variables related to the water level in the rice field.

\begin{tabular}{l|c|c}
\hline & Correlation Coefficient & Significance \\
\hline & & \\
& & \\
Dissolved Oxygen & & $\mathrm{NS}$ \\
pH & 0.004 & $\mathrm{NS}$ \\
Conductivity & 0.03 & $* *$ \\
Temperature & -0.271 & NS \\
Total Organic Matter & -0.235 & $*$ \\
Total Suspended Solids & 0.029 & $* *$ \\
Phosphate & -0.155 & $* *$ \\
Nitrate Nitrogen & -0.329 & \\
& -0.409 & \\
& & \\
\hline
\end{tabular}

* Significance level at $\mathrm{P}<0.05$

** Significance level at $\mathrm{P}<0.01, \mathrm{NS}=$ Not Significant 

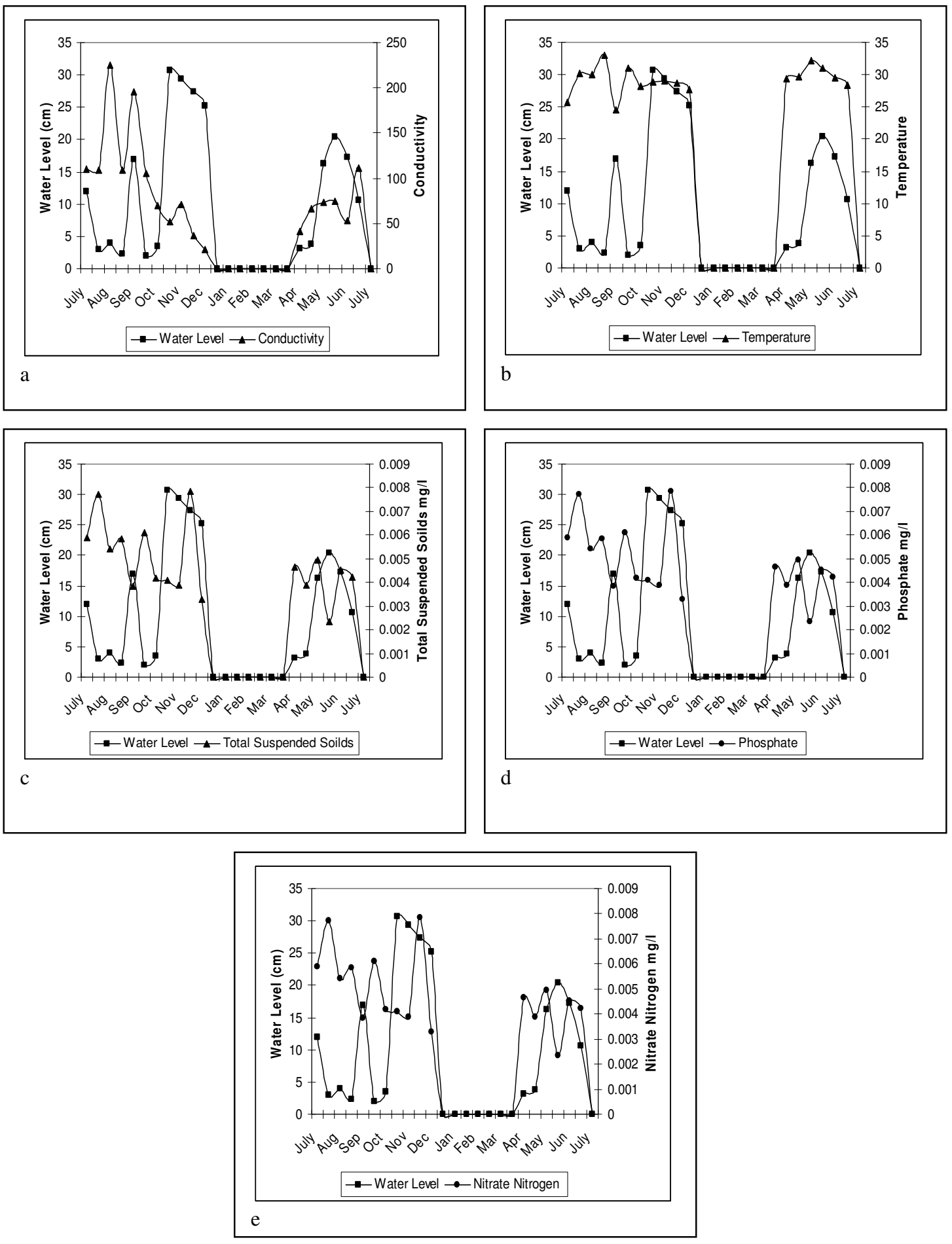

Figure 2. Water level in the rice field in relation with a: conductivity, $b$ : temperature, $c$ : total suspended solids, $d$ : phosphate, e: nitrate nitrogen. 


\section{Discussion}

Generally, this field showed wide ranges in physico-chemical conditions such as temperature, dissolved oxygen, $\mathrm{pH}$, and conductivity due to its shallowness, growth of macrophytes and inputs of nutrients (Lim, 1990).

Ali and Ahmad (1988) reported that the water temperature in the tropics varies from as low $24{ }^{\circ} \mathrm{C}$ in the morning or during cloudy or rainy days and up to $40{ }^{\circ} \mathrm{C}$ on hot sunny days. The temperature of the water in the field is affected directly by the height of the plants. In this rice field the water temperature was varied from 23 to 34 with a mean of 29.21. These values fell with the reported temperature range but slightly lower possibly due to difference in geographical locations and irrigation regime as well. In a rain fed rice field, Che Salmah et al. (1998) reported that the water temperature of a rain fed rice field ranged from 26.4 to $39.7^{\circ} \mathrm{C}$. Lim et al. (1984) recorded that the mean temperature in a rice field could reach as high as $40.1^{\circ} \mathrm{C}$ due to shallow water. When exposed to strong sunlight, the water was heated up readily, especially in the early stages of the rice growing phases when it lacked vegetational cover.

In the rice field the amount of dissolved oxygen increases due to photosynthesis by algal populations. In the present study, the dissolved oxygen was fairly low with a mean of $2.87 \mathrm{mg} \mathrm{L}^{-1}$. In a rain fed rice field, Che Salmah et al. (1998) recorded that dissolved oxygen levels fluctuated considerably, ranging between 1.65 to $5.68 \mathrm{mg} \mathrm{L}^{-1}$. it has been reported that the strong wind passing and shallow water of the rice fields create greater water turbulence, which is rich in dissolve oxygen $\left(6.7 \mathrm{mg} \mathrm{L}^{-1}\right)$. In contrast, stagnant water at the edge of rice field has very little oxygen $\left(1.7 \mathrm{mg} \mathrm{L}^{-1}\right.$ ) (Ali and Ahmad, 1988). However, Lim et al. (1984) recorded that the dissolved oxygen of another Malaysian rice field in Tanjung Karang was very high with a mean $8.6 \mathrm{mg} \mathrm{L}^{-1}$. Similarly, in one of the Netherlands rice field, Fores (1992) recorded a wide range of dissolved oxygen from 2.83 to $11.1 \mathrm{mg} \mathrm{L}^{-1}$.

Generally, the $\mathrm{pH}$ values in paddy fields differ following rice phases during the cultivation period (Fores, 1992). In this study, the $\mathrm{pH}$ mean showed that the rice field was slightly acidic and the value similar to what have been reported in other Malaysian rice fields earlier (Lim et al., 1984 and Che Salmah et al., 1998). The decomposed rice stalks from previous season and weeds especially after herbicide applications, contribute to the acidity of the rice environment (Ali and Ahmad, 1988). Additionally, $\mathrm{pH}$ is influenced by the metabolic activity of the flora particularly photosynthesis. The lower values of the $\mathrm{pH}$ could also be attributed to the presence of substantial amounts of organic matter, associated with $\mathrm{CO}_{2}$ production and nitrogen mineralization (Ali and Ahmad, 1988).

The values of recorded conductivity was lower compared to those reported in a Malaysian rice field study conducted by Lim et al. (1984) but it was higher compared to those in the study of Che Salmah et al. (1998). However, they were similar to the mean values in the study of Helliwell and Stevens (2000) who recorded the same mean values of conductivity in a rice field in New South Wales in Australia of 90.2 and $172.3 \mu \mathrm{S}$ $\mathrm{cm}^{-1}$. These differences of conductivity values were due to the inflow of water, nutrients cycling within the rice fields and fertilization process (Helliwell and Stevens, 2000; Stevens et al., 2006). The applications of fertilizers and pesticide contribute significantly in changing the ion contents of the water and the chemical properties as well (Lim, 1990).

Seasonal factors could have accounted for the fluctuations in $\mathrm{NO}_{3}$ and $\mathrm{NH}_{4}$ levels. Rainfall which supplies mineral nitrogen in the form of $\mathrm{NO}_{3}$ and $\mathrm{NH}_{4}$ is an important

APPLIED ECOLOGY AND ENVIRONMENTAL RESEARCH 8(1): 11-18. http://www.ecology.uni-corvinus.hu • ISSN 15891623 (Print) • ISSN 17850037 (Online) (c) 2010, ALÖKI Kft., Budapest, Hungary 
factor (Heckman, 1979). Other probable causes of $\mathrm{NH}_{3}$ fluctuations were fertilizer applications and high utilization rate by rice plants (Ali and Ahmad, 1988). The concentration of nitrate-nitrogen was higher than that observed in the rice fields in Titi Serong (Ali and Ahmad, 1988) which ranged from 0.22 to $0.75 \mathrm{mg} \mathrm{L}^{-1}$. The difference was justified as the effects of the fertilization process (Ali and Ahmad, 1988), agricultural activities and high activity of the nitrification bacteria (Law and Mohammad Mohsin, 1980). While the mean value of phosphate in the rice field water (mainly due to the fertilization and pesticide application), was high compared to those observed in streams (Ali et al., 1998, 2002, 2003).

The nature of the muddy environment of rice agroecosystem indicates high values of total suspended solids. Although the high densities of phytoplankton in the rice field contributed to increase of contents of suspended solids (Che Salmah, 1996), the mean value of total suspended solids in this rice field was lower than those observed in the polluted Kelang River (Law and Mohammad Mohsin, 1980). It is quite obvious that there is a great difference between lotic and lentic environments, that the streams receive higher level of disturbance and turbidity due to the running velocity. However, high value of total organic matter of this rice field sediment was the result of fertilization during cultivation activities that supported dense floral growth and decaying of macrophytes.

Usually phosphate concentrations are high during the early growing season due to the fertilization process in the field. Low concentrations appear at the end of the season when most of the phosphate has been utilised by rice plants (Cheah and Lai, 1990). Fertilizations and insecticide application might have caused increases of phosphate concentration in the study field. High levels of phosphate concentration could be related to low water levels which might cause muddy environment (Che Salmah, 1996) as well as the phosphate utilisation rate of rice plants (Cheah and Lai, 1990).

Like other aquatic ecosystem, the nutrient cycle and ecological interaction between the aquatic communities in the rice field could cause intermittent changes in chemical and physical characteristics of the rice field water. Additionally, in the rice field the cultivation practices such as plouging, harvesting, desiccation, and application of chemicals, appeared to have a significant role in changing the quality of the field water physically and chemically.

\section{Conclusion}

The rice field is a unique man-made environment with variety of aquatic organisms and their dynamic population, abundance and diversity is closely related to the environmental changes in the rice fields. This study investigated the effect of the cultivation practices on the physical and chemical properties of the water. These findings will effectively contribute toward more understanding about the chemical and physical environment of the rice agroecosystem.

Acknowledgements. The authors are grateful to the Agricultural Department of Sebrang Perai Penang, for allowing us to use their rice plots at Bukit Merah for this study. Sincere thanks are due to Universiti Sains Malaysia (USM) for providing facilities and vehicles to the study site. This research was funded by USM short term research grant NO 304/PBIOLOGI/635047.

APPLIED ECOLOGY AND ENVIRONMENTAL RESEARCH 8(1): 11-18. http://www.ecology.uni-corvinus.hu • ISSN 15891623 (Print) • ISSN 17850037 (Online) (C) 2010, ALÖKI Kft., Budapest, Hungary 


\section{REFERENCES}

[1] Ali, A.B., Ahmad, M. (1988): Water quality in rice field and sump Ponds and its relationship to phytoplankton growth in rice field fish culture system. - Tropical Ecology 29: 63-70.

[2] Ali, A., Reddy, K.R., de Busk, W.F. (1998): Seasonal changes in sediment and water chemistry of a subtropical shallow eutrophic lake. - Hydrobiologia 159: 159-167.

[3] Ali, A., Frouz, J., Lobinske, R.J. (2002): Spatio-temporal effects of selected physicochemical variables of water, algae and sediment chemistry on the larval community of nuisance Chironomidae (Diptera) in a natural and man-made lake in central Florida. Hydrobiologia 470: 181-193.

[4] Ali, A., Lobinske, R., Frouz, J., Leckel, R.J. (2003): Spatial and temporal influence of environmental conditions on benthic macroinvertebrates in Northeast Lake Jesup; Central Florida. - Florida Scientist 66(2): 69-83.

[5] Che Salmah, M.R. (1996): Some aspects of biology and ecology of Neurrothemis tullia (Drury) (Odonata: Libellulidae) in laboratory and rain rice field in Peninsular Malaysia. Unpublished Ph.D. thesis, Universiti Pertanian Malaysia, Serdang, Selangor, Malaysia.

[6] Che Salmah, M.R., Hassan, S.T.S., Abu Hassan, A., Ali A.B. (1998): Influence of physical and chemical factors on the larval abundance of Neurothemis tullia (Drudy) (Odonata: Libellulidae) in a rice field. - Hydrobiologia 389: 193-202.

[7] Cheah, D.K., Lai, H.C. (1990): Ciri limnololgi tentang sepetak sawah padi di Pulau Pinang. - Sains Malaysiana 19: 115-127.

[8] Faithful, N.T. (2002): Methods in agricultural chemistry analysis. - CABI publishing, UK.

[9] Fores, E. (1992): Nutrient loading and drainage channel response in a rice field system. Hydrobiologia 230: 193-200

[10] Heckman, C.W. (1979): Rice field ecology in Northeastern Thailand. - Dr. W. Junk by publishers. - The Huge, Boston-London, UK.

[11] Helliwell, S., Stevens M.M. (2000): Efficacy and environmental fate of alphacypermethrin applied to rice fields for the control of chironomid midge larvae (Diptera: Chironomidae). - Field Crop Research 67: 263-272.

[12] Law, A.T., Mohammad Mohsin, A.K. (1980): Environmental studies of Kelang River chemical, physical and microbiological parameters. - The Malayan Nature Journal 33(3,4): 175-187.

[13] Lim, R.P., Abdullah, M.F., Fernando, C.H. (1984): Ecological studies of Cladocera in the rice fields of Tanjung Karang, Malaysia, subjected to pesticide treatment. Hydrobiologia 113: 99-103.

[14] Lim, R.P. (1990): Effects of pesticides on the aquatic invertebrate community in rice fields. Proceedings of the International Conference on Tropical Biodiversity - In Harmony with Nature, 12-16 June 1990, Kuala Lumpur, Malaysia. pp 336-352.

[15] Stevens, M.M., Helliwell, S., Cranston, S.P. (2006): Larval chironomid communities (Diptera: Chironomidae) associated with establishing rice crops in New Southern Wales, Australia - Hydrobiologia 556(1): 317-325.

[16] Tomar, M. (1999): Quality assessment of water and waste water. - Lewis Publishers, New York.

APPLIED ECOLOGY AND ENVIRONMENTAL RESEARCH 8(1): 11-18. http://www.ecology.uni-corvinus.hu • ISSN 15891623 (Print) • ISSN 17850037 (Online) (c) 2010, ALÖKI Kft., Budapest, Hungary 